\title{
Market failure as ignored determinant of the choice between public and business administration
}

\author{
GaYlord GeORge CANDLER \\ UNIVERSITY OF NORTH FLORIDA, MPA PROGRAM, USA \\ JoHn PAUl RANDLE \\ UNIVERSITY OF NORTH FLORIDA, MPA PROGRAM, USA
}

\begin{abstract}
In the epistemology of administrative science, one of many important dimensions has been the different subfields of the study of administration. Perhaps the biggest, longest running 'turf' battle between these different areas of administrative knowledge is that between public and business administration. This is a controversy that goes back at least to Adam Smith, with his specific limitation of the role of 'the sovereign' (government, or public administration) to justice, defense, and public works. In limiting government to these areas, note that Smith was also implicitly asserting that these were market, or 'invisible hand' failures: areas where the pursuit of self-interest would not yield the good of society, the specific moral justification Smith identified for market exchange. Contemporary discussions of the relative role of market and state are generally framed in terms of the role of the State, with market provision the default option. We will argue that even discussions of the role of the State can best be assessed through the concept of market failure. The nine broad types of market failure discussed include institutions, public goods, monopoly, asymmetric information, externalities, substantive issues, principal/agent problems, irrationality, and the implications of 'creative destruction'.
\end{abstract}

Keywords: Market failure. The role of government. Substantive issues. Consumer irrationality. Creative destruction.

\section{Falha do mercado como determinante ignorada na escolha entre administração pública e empresarial}

\section{Resumo}

Na epistemologia da ciência administrativa, uma das muitas dimensões importantes é a das diferentes subáreas do estudo de administração. Talvez a maior e mais longa batalha entre essas subáreas seja a travada entre a administração pública e a empresarial. É uma controvérsia que remonta os estudos de Adam Smith, em que o papel do 'Soberano' (governo, ou administração pública) é limitado especificamente a justiça, defesa e obras públicas. Ao limitar a ação do governo a essas três áreas, Smith implicitamente as considerou como falhas de mercado, ou falhas da "mão invisível", isto é, áreas em que a busca pelo auto-interesse não resulta no bem da sociedade (que é a justificativa moral identificada por Smith para a troca de mercado). As discussões atuais sobre os papéis do mercado e do Estado são geralmente estruturadas em termos do papel do Estado, com a oferta do mercado como opção padrão. Neste artigo argumentamos que até as discussões sobre o papel do Estado podem ser melhor avaliadas através do conceito de falha de mercado. Os nove tipos mais abrangentes de falha de mercado discutidos incluem instituições, bens públicos, monopólio, informação assimétrica, externalidades, questões substantivas, problemas principalagente, irracionalidade e as implicações da "destruição criativa".

Palavras-chave: Falha do mercado. Papel do governo. Questões substantivas. Irracionalidade do consumidor. Destruição criativa.

\section{Falla del mercado como factor determinante ignorado en la elección entre administración pública yempresarial}

\section{Resumen}

En la epistemología de la ciencia administrativa, unas de las muchas dimensiones importantes han sido los diferentes subcampos del estudio de la administración. Quizás la más grande y larga batalla entre estas diferentes áreas del conocimiento administrativo, es la que existe entre la administración pública y la empresarial. Esta es una controversia que se remonta, por lo menos, a Adam Smith, con su limitación específica del papel del "soberano" (Gobierno, o administración pública) a la justicia, defensa y obras públicas. Al limitar al gobierno a estas áreas, nótese que Smith también afirmaba implícitamente que se trataba de fallas del mercado, o de manos invisibles: áreas donde la búsqueda del interés propio no resultaría en el bien de la sociedad, que es la justificación moral específica que Smith identificó para el intercambio de mercado. Las discusiones contemporáneas sobre el rol relativo del mercado y del Estado generalmente se estructuran a los efectos de justificar el rol del Estado, con la provisión del mercado como la opción predeterminada. Argumentamos que las discusiones sobre el papel del Estado se pueden evaluar mejor a través del concepto de falla del mercado. Los nueve tipos generales de fallas de mercado discutidos incluyen instituciones, bienes públicos, monopolio, información asimétrica, externalidades, cuestiones sustantivas, problemas de principal/ agente, irracionalidad, y las implicaciones de la "destrucción creativa".

Palabras-clave: Falla del mercado. Papel del Gobierno. Cuestiones sustantivas. Irracionalidad del consumidor. Destrucción creativa. 


\section{INTRODUCTION}

In the epistemologia da ciência da administração one of many important dimensions has been the different subfields of the study of administration. At our university alone, we have graduate programs in business administration, global business administration, health administration, public administration, nonprofit management, educational leadership, sport management, and higher education administration. It is often relatively simple to identify social realms in which these different sub-fields should apply: in the provision of health and in managing hospitals, the Master of Health Administration; in the provision of education in universities, the Master of Higher Education Administration. Perhaps the most important, and longest running 'turf' battle between these different areas of administrative knowledge is that between public and business administration. That business administration should apply to business, and public administration to government, is relatively well accepted (though it is a commonplace in the USA to hear politicians tout their small business experience as qualification for public office $^{1}$ ). What is more contentious is what each institution should do: should government or business produce and distribute bread, education, haircuts, defence, electricity, water, and other goods and services? This is a controversy that goes back at least to Adam Smith, with his specific limitation of the role of 'the sovereign' (i.e. government, or public administration) to justice, defense, and public works (SMITH, 1776, Book II, p. 208-9). Implicitly Smith suggested that these were market failures, or areas where the 'invisible hand' would fail to yield the specific purpose Smith identified for markets: the good of society.

Contemporary discussions of the relative role of market and state are generally concerned with justifying the role of the State. Market provision is the default option, not requiring justification; while the state is subject to incessant criticism. We argue that even discussions of the role of the State can best be assessed through the concept of market failure. Market failure has, though, been marginalized even within the field of economics, as equilibrium theory is applied without recognition of these limits (FINER, 1945; GALBRAITH, 1973, p. 11-50). Instead, general market equilibrium is reified. Consumer and producer surplus are identified as shaded areas in the left quadrant of the ' $x$ ' formed by the intersection of upward sloping supply, and downward sloping demand curves. Any deviation (especially as a result of public action!) from market equilibrium is shown as reducing this surplus, and so resulting in the evocatively named "deadweight loss" (SAMUELSON and NORDHAUS, 1985, p. 431-2; KRUGMAN and WELLS, 2009, p. 180-2), in which "economic efficiency would be violated and inefficiency would result" (GWARTNEY, STROUP and SOBEL, 2000, p. 75-6).

Economics textbooks structurally perpetuate this conception. The first few chapters present, and justify the conceptual usefulness of the assumption of 'perfect markets'. The supply and demand curves are then derived, and the point at which they cross is a utility maximizing equilibrium. As indicated: no deviation from this position is permitted. Some chapters later, most economics texts present a few chapters on a handful of market failures: public goods, monopoly, and asymmetric information being especially common. But the texts do not, then, return to that initial assumption of perfect markets, and correct the inviolability of market equilibrium. In contrast to these uncritical advocacies of markets in the business administration literature; in the (English language) public administration literature, some of the seminal texts in the field are criticisms of government, and advocate markets (see SIMON, 1945; 1969; OSTROM, 1973; OSBORNE and GAEBEL, 1992; WILSON, 1989). Market failure is again ignored.

\section{MARKET FAILURE}

This paper focuses on market failure, in large part because the authors, as North Americans, live in one of the most marketfriendly societies in the world, and in which the role of government has, arguably, long been under attack (see GALBRAITH, 1973, p. 4-9; DIMOCK, 1990, p. 22), even though the size of government has been decreasing for much of the past 30 years (see THE FISCAL, 2012). The discussion that follows will present nine broad categories of market failure that, we argue, go at least half way (with government failure being the other half) to giving those interested in a vida humana associada (GUERREIRO

\footnotetext{
${ }^{1}$ While this paper was initially being prepared, an election campaign was underway in our home city of Jacksonville, Florida. The party-endorsed Republican candidate won, despite having no experience in government service. Instead, he touted himself as "a job creator," having "co-founded a Jacksonville-based professional services firm" (CURRY, 2015). Since that first draft of this paper the United States has seen a new administration take office at the federal level, with again historic low levels of government experience (for three critical conservative perspectives, see DINAN, 2016; SMARICK and HAMILTON, 2017; COFFEY, 2016)
} 
RAMOS, 1989, p. xix-xx), a better understanding of how to choose between public, private, nonprofit, co-produced, or self production of goods and services. These nine market failures are:

1. Institutions (or justice?)

2. Public goods

3. Monopoly

4. Asymmetric information

5. Externalities

6. Substantive issues

7. Principal/agent problems

8. Irrationality

9. Implications of creative destruction

Given the challenge this paper presents to mainstream economic theory, the case that market failure has been ignored is made within that same theoretical world, with reference to seminal works in the economic literature.

\section{INSTITUTIONS}

That contemporary economics has ignored market failure is especially odd given that a number of market failures were evident as long ago as Adam Smith's An Inquiry into the Nature and Causes of the Wealth of Nations, widely considered the first systematic discussion, and advocacy of market economics, at least in English. Smith especially addressed the concept of market failure in terms of his 'Three Duties of the Sovereign'. The first of these was justice. Smith described this duty as "... that of protecting, as far as possible, every member of the society from the injustice or oppression of every other member of it" (Book II, p. 231).

That justice is a fundamental role of government is a point that requires little elaboration. More recently it is worth noting that even the World Bank, hardly a staunch advocate of government, has stated that: "An effective state is vital for the provision of the goods and services - and the rules and institutions - that allow markets to flourish and people to lead healthier, happier lives. Without it, sustainable development, both economic and social, is impossible" (WORLD BANK, 1997, p. 1).

Further on the subject of institutions, Smith's third duty of the sovereign was "public works and institutions." Public works will be described in the next section. By "public institutions" Smith meant public education:

After the public institutions and public works necessary for the defence of the society, and for the administration of justice, both of which have already been mentioned, the other works and institutions of this kind are chiefly those for facilitating the commerce of the society, and those for promoting the instruction of the people. The institutions for instruction are of two kinds: those for the education of youth, and those for the instruction of people of all ages [...] (Book II, p. 244).

\section{PUBLIC GOODS}

Smith's third duty of the sovereign also identified infrastructure: roads, bridges, harbours and the like. His 1776 case for public goods was a bit vague, arguing that some infrastructure that benefits the economy greatly, might be such that the private provider of the work would not be able to profit from this. As a result, government would need to provide the infrastructure (Book II, p. 244). This is certainly reflected in Brazilian research, for instance, in Mussolini and Teles' (2010) analysis showing a correlation between infrastructure and productivity.

Paul Samuelson went on to develop the logic of this further, through first distinguishing between private and collective consumption goods. As examples, think of bread versus clean air. While both are desirable, in the former case the buyer enjoys 
the full benefit of a loaf of bread. In the latter case clean air can be enjoyed even by those who have not contributed to its preservation (SAMUELSON, 1954, p. 387-9). The same logic applies to defence, Smith's second 'duty of the sovereign', and the logic of public education would also apply to public health (BOEIRA, 2002). Or, in the evocative phrase that has come to be associated with this phenomenon, "if a good is nonexcludable, rational consumers won't be willing to pay for it - they will take a 'free ride' on anyone who does pay. So there is a free rider problem" (KRUGMAN and WELLS, 2009, p. 462).

\section{MONOPOLY}

As Cassidy put it: "The problem of monopoly is as old as economics" (2009, p. 128). The danger of monopoly and, implicitly, the need for something to combat this, is more implied than openly stated in The Wealth of Nations. In his discussion of the wages of labour, Smith notes that bargaining between masters and workmen is inherently unfair, as "the masters, being fewer in number, can combine more easily; and the law, besides, authorizes, or at least does not prohibit their combinations, while it prohibits those of the workmen" (p. 74-5, see also p. 69).

Economics has not necessarily handled the topic of monopoly well. Harberger's 1954 study argued that the cost of monopoly to US society was a fraction of a percent of GDP. Rather than regulation as a solution to this problem, economists have often seen regulation as the cause. For the Friedmans, "a monopoly can seldom be established within a country without overt and covert government assistance" $(1979$, p. 45). Still, the topic has long been a topic of interest among economists (PIGOU, 1920, p. 250-380; SCHUMPETER, 1942, p. 87-106; SAMUELSON and NORDHAUS, 1985, p. 502-27; KRUGMAN and WELLS, 2009, p. 355-81).

\section{ASYMMETRIC INFORMATION}

The classic work on asymmetric information was Akerloff's (1970) "The Market for 'Lemons': Quality Uncertainty and the Market Mechanism." The central message was that the seller often knows more about the quality of a good than does the buyer. Given the assumption of perfect information in perfect markets, this creates an obvious, utility-reducing market failure.

The problem goes beyond the purchase of used cars. Consumer safety is also a critical area of information asymmetry. One can think of the use of tobacco. While there is little excuse for the contemporary consumer to be unaware of the negative health effects of tobacco, and so continued use probably applies as much to the market failure 'irrationality' discussed below; an element of the early campaign against tobacco was precisely to inform smokers of the risks (see BOEIRA, 2002, p. 79-91 and 262-72). Cassidy notes a number of other examples: "In the labor market, employers know much less about the skills and diligence of job applicants than the applicants themselves. In banking, lenders know less about borrowers' ability to repay their loans than the borrowers do. In health care, the providers of medical insurance know less about the health of their customers than the customers do" (2009, p. 153-4).

\section{EXTERNALITIES}

Coase's (1960) "The Problem of Social Cost" identified externalities as a form of market failure. The term 'external' refers to costs borne (or less often: benefits received) that are outside of the immediate exchange between buyer and seller. For market theory, equilibrium is the point at which both buyer and seller maximize their utility, with the benefits of an exchange greater than costs (purchase price for the buyer, production costs for the seller). In the case of externalities, a third party external to, or outside this exchange, bears costs.

Coase emphasized, especially, the importance of weighing the costs of the externality against the benefits produced, with the agent suffering the effects of the externality adequately compensated if benefits exceeded costs. He was also, somewhat 
ironically, generally skeptical of the ability of government agencies to resolve such conflicts through regulation, indeed he argued these were likely to protect those causing the externalities (p. 26-8). He had much more confidence in the ability of the Courts (and Judges, their government agents) to do so (p. 19).

The recent drought in southern Brazil (with São Paulo getting much of the world's attention) provides a relevant illustration. The Economist (2014) puts the blame for the problem squarely on citizens: "The average resident of São Paulo still consumes roughly 200 litres of water a day, well above the 150 litres in much of Europe" (no page). This, though, is precisely the sort of 'tragedy of the commons' in which private choices, aggregated, may destroy a resource (OLIVEIRA FILHO, 2015).

\section{SUBSTANTIVE ISSUES}

Candler argues that "contemporary economics" has "sought to remove egalitarian normative considerations from economics" (2010, p. 329). He especially sees the roots of this trend originating in Alfred Marshall's attempt to remove normative considerations from economics, especially notable given A.C. Pigou's counter perspective which sought to maintain pursuit of social welfare at the center of economics (CANDLER, 2010, p. 333-5; MARSHALL, 1920, p. vi; PIGOU, 1920, p. 11-20).

Therefore it is little surprise that what we are referring to as 'substantive issues' is not a major focus of the little research mainstream contemporary economists have done on market failure. However a number of people (of all political leanings) argue that governance of society should be about more than just efficiency and the provision of goods and services. Alberto Guerreiro Ramos argued that in contemporary public administration "...questions like the 'good' of man or society have no place in the area of rational debate. Rational man is unconcerned with the ethical nature of ends per se. He is a calculative being intent only on accurately finding adequate means to accomplish goals" (1981, p. 106). And so instead, for Ramos public administration needed to concern itself with issues like "love, trust, honesty, truth, and self-actualization" (p. 112).

More broadly, 'substantive issues' would include contemporary topics like social capital, civic responsibility, and concerns over inequality. Again, there are roots of these concerns going back to Adam Smith. His famous 'invisible hand' quote identifies the interest of society as the end to which self-interest is harnessed (1776, p. 477-8). Smith also raises the issue of equity: "It is but equity, besides, that they who feed, cloath and lodge the whole body of the people, should have such a share of the produce of their own labour as to be themselves tolerably well fed, cloathed and lodged" (p. 88).

\section{PRINCIPAL/AGENT PROBLEMS}

When the people hired to manage firms put their own interests ahead of the firm, market distortions result. Berle and Means' (1932) The Modern Corporation and Private Property is generally considered the seminal statement of this problem. The central issue is what has come to be termed the separation of ownership (i.e. by shareholders, the principal) and control (i.e. by executives, their agent). If the interests of (and incentives faced by!) the latter are inconsistent with the interests of the former, owners may lose (p. 112-16).

These issues have been developed in a number of directions that are far beyond the scope of this short paper, both in the business management and broader social science literature. For our purposes, Fama and Jensen especially emphasized different (principal v. agent) attitudes to risk (1983, p. 305-11). They also, it should be added, extended principal/agent tensions to nonprofit organizations (p. 318-21). Jensen has returned to this topic more recently. In contrast with Berle and Means' characterization of one interest of shareholders as "that the company should be made to earn the maximum profit compatible with a reasonable degree of risk" (1932, p. 114), Jensen describes as "managerial heroin" the use of stock options as an incentive for (mis)management (2005, p. 8-14). This, too, was before the global financial catastrophe that was the Bush recession of 2007 and beyond, attributed in large part to executive risk taking (GREENSPAN, 2008; CASSIDY, 2009, p. 205-98; ROUBINI and MIHM, 2010, p. 61-85). 
Finally, it should be added that while the discussion above is set in the private, principal-agent problems occur in government, as well. Indeed, government regulatory failure (as often as not encouraged by lobbying on the part of the private interests who benefit from either regulation or deregulation) is widely cited as a contributing factor in the recent recession (ROUBINI and MIHM, 2010, p. 68-76 and 211-37). More, government can also be captured from within. It is concerns like this that have led to Bresser Pereira calling for "os direitos dos cidadãos de que o patrimônio público seja efectivamente de todo a para a todos... contra aqueles que buscam capturer privadamente os bens que são ou devem ser de todos" (1997, p. 109).

\section{IRRATIONALITY}

An underlying assumption of (especially micro-) economics has been rationality. As Samuelson \& Nordhaus put it: "People have rational expectations when their forecasts are unbiased and they use all available information" (1985, p. 335). This belief was emphasized by 'Austrian economics'. Von Mises, for instance, sought to "convert the theory of market prices into a general theory of human choice" $(1949$, p. 3). Central to this was methodological individualism (p. 41-44) with its assumption that "human action is necessarily always rational" (p. 18) to the individual actor, and so government intervention was less likely to lead to outcomes that benefit the public than would the aggregated private decisions of citizens themselves (GALBRAITH, 1958, p. 11-18; HAYEK, 1944, p. 75-79).

While even The Wealth of Nations offered examples of irrational economic behavior, Herbert Simon is generally credited with the first systematic refutation of these assumptions of human rationality. He especially identified limited information and computational capacities (1955, p. 99) and so "actual human rationality-striving can at best be an extremely crude and simplified approximation to the kind of global rationality that is implied" (p. 101) by contemporary economics. More recently the 'behavioral model' identified by Simon has been taken up by a range of economists (THE ECONOMIST, 1999). Identifying Von Mises' ideas above as part of the problem, Cassidy argues that "It was in the aftermath of World War II that economists began to focus almost exclusively on Homo economicus, elevating rationality to a near-sacred principle. By the 1970s, economists had locked themselves in straitjackets" (2009, p. 193). Even after the Bush Recession and onwards, which occurred despite conservative think tanks ranking the US as one of the most free economics in the world in $2008^{2}$, many mainstream economists blamed the financial meltdown on too much government (CASSIDY, 2010).

\section{IMPLICATIONS OF CREATIVE DESTRUCTION}

Austrian economist Joseph Schumpeter famously defended the logic of capitalism as follows:

"The opening up of new markets, foreign or domestic, and the organizational development from the craft shop and factory to such concerns as U.S. Steel illustrate the same process of industrial mutationif I may use that biological term-that incessantly revolutionizes the economic structure from within, incessantly destroying the old one, incessantly creating a new one. This process of Creative Destruction is the essential fact about capitalism. It is what capitalism consists in and what every capitalist concern has got to live in." (1942, p. 83).

This is all well and good, so long as the costs of the destruction do not overwhelm the benefits thereby 'created'. So if your favorite bakery goes broke: no worries, you can get bread elsewhere. But if your child's for-profit school is shut down, your child could lose, or experience severe disruption to, a year of education. Another dimension of the creative destruction of capitalism can be seen more broadly. The basic logic is that the inefficient is swept away, to be replaced by the more efficient.

${ }^{2}$ The libertarian Cato Institute's Economic Freedom of the World: 2010 Report, using 2008 data, had the US ranked sixth, behind only Hong Kong, Singapore, New Zealand, Switzerland and Chile. The über-conservative Heritage Foundation's Index of Economic Freedom 2008 similarly had the US ranked fifth, with Hong Kong, Singapore, Ireland and Australia ahead. Ipso facto: whatever caused the Bush recession, it was not too much government. 
Resources, especially labour, idled by the destruction of inefficiencies are (it is implied) taken up by the more efficient production methods. A number of problems can result, though:

- The idled worker may not have the skills needed by the more efficient production methods (see BESSEN, 2014; SCHUMPETER, 1942, p. 134-9).

- Idled regions that lose their industry may not see something comparable (or much of anything) replace this. In Brazil, think of mechanization in the sugar industry, and agro-industry in general (MARTINE, 1991). In the United States the textile industry shifted from New England to North Carolina in search of cheaper labor, then from North Carolina overseas, again in search of cheaper labor. Neither region has recovered (see KENNEDY, 1954; THE ECONOMIST, 2005).

- Whole countries may be left out of the global trading system (see CARDOSO, 2001, p. 151-6).

\section{BY WAY OF CONCLUSION}

In closing, we would like to return to the question raised earlier about differences in the relative utilization of markets rather than government in the US and Brazil. Too often, discussions of what Hood (1986) termed "the tools of government" suffer from a number of maladies. One of these is the tendency to think in ideological, rather than pragmatic terms. A second is that it is often implied that there is 'one best way', or one best model. Instead, as Guerreiro Ramos argued, the social scientist and public manager needs to think in terms of "a multidimensional model of social systems analysis and design in which the market is considered a legitimate and necessary, but limited and regulated social enclave" (1989, p. 140). Implementing such a model will have a greater likelihood of success if based on a balanced understanding of market failure, along with an appreciation of the limits of government action. Instead, too much of contemporary economics has featured an ideological bias that exaggerates the limitations of government action, while the reality of market failure, developed within the economics literature itself, has been marginalized. 


\section{REFERENCES}

AKERLOFF, G. The Market for 'Lemons': Quality Uncertainty and the Market Mechanism. The Quarterly Journal of Economics, v. 84, n. 3, p. 488-500, 1970.

BERLE, A.; MEANS, G. The Modern Corporation and Private Property. New York: Harcourt, Brace \& World, 1932.

BESSEN, J. Employers Aren't Just Whining - the 'Skills Gap' is Real. Harvard Business Review, 25 August, 2014. Available at: < https:// hbr.org/2014/08/employers-arent-just-whining-the-skills-gap-isreal>. Accessed on: 1 December 2017.

BOEIRA, S. L. Atrás da cortina de fumaça. Itajai: Editora Univali, 2002.

BRESSER PEREIRA, L. C. Cidadania e Res Publica: A Emergência dos Direitos Republicanos. Revista de Filosofia Política, v. 1, p. 99-144, 1997.

CANDLER, G.G. Toward a Public-Spirited Public Management Economics: An Essay in Honor of John Kenneth Galbraith. Administrative Theory \& Praxis, v. 32, n. 3, p. 328-48, 2010.

CARDOSO, F. H. Charting a New Course. New York: Rowan and Littlefield, 2001.

CASSIDY, J. How Markets Fail. New York: Farrar, Straus and Giroux, 2009.

CASSIDY, J. After the Blowup. The New Yorker, 11 January, no pages, 2010. Available at: < https://www.newyorker.com/magazine/2010/01/11/ after-the-blowup>. Accessed on: 1 December 2017.

CATO INSTITUTE. Economic Freedom of the World 2010. Vancouver: Fraser Institute, 2010.

CITY OF JACKSONVILLE. About the Mayor. Office of Mayor Lenny Curry, Jacksonville, Florida. Available at: < http://www.coj.net/ mayor-curry.aspx>. Accessed on 1 December 2017.

COASE, R. H. The Problem of Social Cost. The Journal of Law and Economics, v. 3, p. 1-44, 1960.

COFFEY, B. Trump's \$6 Billion Cabinet: Mostly Men, Mostly White and Not Much Government Experience. Bloomberg Politics, 15 December, 2016. Available at: <https://www.bloomberg.com/graphics/2016trump-cabinet/>. Accessed on: 1 December 2017.

CURRY, L. Lenny Curry For Mayor, Jacksonville, 2015. Available at: <http://www.lennycurryformayor.com/about/>. Accessed on: 17 July 2015.

DIMOCK, M. The Restorative Qualities of Citizenship. Public Administration Review, v. 62, n. 1, p. 21-5, 1990.

DINAN, S. Donald Trump hit for assembling team lacking executive experience to run massive federal agencies. The Washington Times, 5 December, 2016. Available at: <http://www.washingtontimes. com/news/2016/dec/5/donald-trump-choices-for-cabinet-lackexecutive-ex/>. Accessed on: 1 December 2017.

THE ECONOMIST. Irrationality: rethinking thinking. 16 December, 1999. Available at: <http://www.economist.com/node/268946>. Accessed on: 1 December 2017.

THE ECONOMIST. Human cost of cheaper towels. 21 April, 2005. Available at: <http://www.economist.com/node/3893663>. Accessed on: 1 December 2017.
THE ECONOMIST. Fiscal cliff: On the edge. 15 December, 2012. Available at: <http://www.economist.com/news/united-states/21568395what-cliff-means-and-why-americas-deficit-woes-are-so-intractableedge>. Accessed on: 1 December 2017.

THE ECONOMIST. Reservoir hogs. 20 December, 2014. Available at <http://www.economist.com/news/americas/21636782-governmentresponded-late-drought-brazils-industrial-heartland-reservoir-hogs $>$. Accessed on: 1 December 2017.

FAMA, E.; JENSEN, M. Separation of Ownership and Control. Journal of Law and Economics, v. 26, n. 2, p. 301-25, 1983.

FINER, H. Road to reaction. Boston: Little, Brown and Company, 1945.

FRIEDMAN, M.; FRIEDMAN, R. Free to Choose. New York: Avon, 1979.

GALBRAITH, J. K. The affluent society. Boston: Houghton Mifflin, 1958.

GALBRAITH, J. K. Economics \& the public purpose. New York: Signet, 1973.

GREENSPAN, A. Testimony delivered before the House Oversight and Government reform Committee. Washington, D.C., 23 October, 2008.

GUERREIRO RAMOS, A. G. A Nova Ciência das Organizações: uma reconceituação da riqueza das nações. Rio de Janeiro: Fundação Getulio Vargas, 1989.

GWARTNEY, J.; STROUP, R.; SOBEL, R. Economics. Fort Worth: Harcourt, 2000.

HARBERGER, A. Monopoly and Resource Allocation. American Economic Review, v. 44, n. 2, p. 77-84, 1954.

HAYEK, F. The road to serfdom. Chicago: University of Chicago Press, 1944.

HERITAGE FOUNDATION. Index of Economic Freedom 2008., 2008. Available at: <http://thf_media.s3.amazonaws.com/index/pdf/2008/ Index2008 ExecutiveSummary.pdf>. Accessed on: 1 December 2017.

HOOD, C. The Tools of Government. London: Chatham, 1986.

JENSEN, M. Agency Costs of Overvalued Equity. Financial Management, v. 34, n. 1, p. 5-19, 2005.

KENNEDY, J. F. New England and the South. The Atlantic, 1 January, 1954. Available at: <http://www.theatlantic.com/magazine/ archive/1954/01/new-england-and-the-south/376244/>. Accessed on: 1 December 2017.

KRUGMAN, P.; WELLS, R. Economics. New York: Worth, 2009.

MARSHALL, A. Principles of Economics. London: MacMillan, 1920.

MARTINE, G. A Trajetória da Modernização Agrícola: A Quem Benefica? Lua Nova, n. 23, março, p. 7-37, 1991.

MUSSOLINI, C. C.; Teles, V. K. Infraestrutura e produtividade no Brasil. Revista de Economia Política v. 30, n. 4, p. 645-62, 2010.

OLIVIERA FILHO, G. R. A Crise da Água na Região Metropolitana de São Paulo em 2014 e a Ineficiente Gestão dos Recursos Hídricos. CES Revista v. 29, n. 1, p. 5-20, 2015.

OSBORNE, D.; GAEBLER, T. Reinventing Government. Reading, Massachusetts: Addison Wesley, 1992. 
OSTROM, V. The Intellectual Crisis in American Public Administration. Tuscaloosa: University of Alabama Press, 1973.

PIGOU, A. The Economics of Welfare. New York: Cosimo, 1920.

ROUBINI, N.; MIHM, S. Crisis Economics. New York: Penguin, 2010.

SAMUELSON, P. The Pure Theory of Public Expenditure. The Review of Economics and Statistics, v. 36, n. 4, p. 387-9, 1954.

SAMUELSON, P.; NORDHAUS, W. Economics. New York: McGraw Hill, 1985.

SCHUMPETER, J. Capitalism, Socialism and Democracy. New York: Howard, 1942

SIMON, H. Administrative Behavior. New York: The Free Press, 1945.

SIMON, H. A Behavioral Model of Rational Choice. The Quarterly Journal of Economics, v. 69, n. 1, p. 99-118, 1955.
SIMON, H. The Sciences of the Artificial. Cambridge: MIT Press, 1969. SMARICK, A.; HAMILTON, K. Government Experience and President Trump's Domestic Policy Cabinet. American Enterprise Institute, February, 2017. Available at <https://www.aei.org/wp-content/ uploads/2017/02/Government-Experience-and-President-TrumpsDomestic-Policy-Cabinet.pdf>. Accessed on: 1 December 2017.

SMITH, A. An Inquiry into the Nature and Causes of the Wealth of Nations. Chicago: University of Chicago Press, 1776.

VON MISES, L. Human action: A treatise on economics. New Haven: Yale University Press, 1949.

WILSON, J. Q. Bureaucracy. New York: Basic Books, 1989.

World Bank. World Development Report 1997. Washington, D.C., 1997.

Gaylord George Candler

PhD in Public Policy from Indiana University; Professor and Director of the Master of Public Administration program, University of North Florida, Jacksonville-FL, USA. E-mail: g.candler@unf.edu

John Paul Randle

Master of Public Administration from the University of North Florida Warehouse Manager, BAE Systems, Jacksonville - FL, USA. E-mail: jpr226@ @hotmail.com 